\title{
ANALISIS IMPLEMENTASI PENGELOLAAN BARANG MILIK DAERAH PADA DINAS PEKERJAAN UMUM DAN PENATAAN RUANG KABUPATEN MERANGIN
}

\author{
Dori Nofriadi ${ }^{1}$
}

\section{${ }^{1}$ Dinas Pekerjaan Umum dan Penataan Ruang Kabupaten Merangin Provinsi Jambi. dorinofriadi@yahoo.coml}

Received :

Accepted : 17 June 2021

Published : 21 June 2021

\section{ABSTRACT}

This study aims to determine how the implementation of regional property management in the Department of Public Works and Spatial Planning, Merangin District which focused on the factors that influence the implementation and the efforts made for the success of policy implementation. This study used a qualitative research method, with 16 informants who were selected using purposive sampling method. The data was analyzed by using qualitative data analysis which divided into five phases, consisting data reduction, data display, triangulation, conclusion drawing, and verification. The results of this study indicate that the implementation of regional property management at the Department of Public Works and Spatial Planning of Merangin Regency has not been optimally implemented according to the policy. On the other hand, the factors that affect the success of implementation include (1) the problem of the location of regional property in 24 Districts of Merangin Regency and low awareness and sense of responsibility as well as the cooperative attitude of personnel in the management of regional property, (2) the recruitment policies for managing assets belonging to the regions is not accurate and measurable, and the lack of socialization to increase the capacity of the managers of regional property, (3) environmental support problems which has the lack of use of technological tools to facilitate work and the inadequate budget so that it is constrained in implementing the management of regional property. The results of this study can be concluded that (1) there is a commitment from the Merangin Regency Government in the field of budgeting to carry out the mandate of Regional Regulation Number 5 of 2017 regarding Management of Local-Owned Assets which can be used for the management of local-owned assets in the local bureaucracy (OPD), and (2) there are efforts to socialize and procure technological devices and to increase the capacity management of local-owned assets in the Merangin District Public Works and Spatial Planning Department.

Keywords : implementation; policies; regional property

\section{ABSTRAK}

Penelitian ini bertujuan untuk mengetahui bagaimana implementasi pengelolaan barang milik daerah di Dinas Pekerjaan Umum dan Penataan Ruang Kabupaten Merangin, apa saja faktor yang mempengaruhi implementasi dan upaya yang dilakukan untuk kesuksesan implementasi kebijakan. Penelitian ini menggunakan metode penelitian kualitatif, dengan informan berjumlah 16 orang yang dipilih dengan menggunakan metode purposive sampling. Sedangkan teknik analisis data menggunakan analisis kualitatif dengan tahapan reduksi data, penyajian data, triungulasi, penarikan kesimpulan dan verifikasi. Hasil penelitian ini menunjukkan bahwa implementasi pengelolaan barang milik daerah pada Dinas Pekerjaan Umum dan Penataan Ruang Kabupaten Merangin belum optimal dilaksanakan sesuai kebijakan, adapun factor-faktor yang mempengaruhi kesuksesan implementasi diantaranya (1) masalah lokasi barang milik daerah berada di 24 Kecamatan dalam Kabupaten Merangin dan masih rendahnya kesadaran serta rasa tanggung jawab maupun sikap kooperatif personil dalam pengelolaan barang milik daerah, (2) masalah kebijakan rekrutmen pengelola barang milik daerah belum tepat dan terukur, serta kurangnya pelaksanaan sosialisasi untuk peningkatan kapasitas pengelola barang milik daerah, (3) masalah dukungan lingkungan dimana masih minimnya penggunaan alat teknologi yang dapat memudahkan pekerjaan dan anggaran yang kurang memadai, sehingga terkendala dalam melaksanakan pengelolaan barang milik daerah. Hasil penelitian ini dapat disimpulkan agar (1) adanya komitmen dari Pemerintah Kabupaten Merangin dalam bidang penganggaran untuk menjalankan amanah Peraturan Daerah Nomor 5 Tahun 2017 tentang Pengelolaan Barang Milik Daerah yang dapat digunakan untuk biaya pengelolaan barang milik di Organisasi Perangkat Daerah (OPD), dan (2) adanya upaya sosialisasi dan pengadaan alat teknologi serta peningkatan kapasitas pengelola barang milik daerah pada Dinas Pekerjaan Umum dan Penataan Ruang Kabupaten Merangin.

Kata Kunci : implementasi; kebijakan; barang milik daerah 
Analisis Implementasi Pengelolaan Barang Milik Daerah Pada Dinas Pekerjaan Umum dan Penataan Ruang Kabupaten Merangin

Dori Nofriadi

\section{PENDAHULUAN}

Dalam rangka mewujudkan good governance, pengelolan barang milik daerah secara profesional merupakan tuntutan yang harus dipenuhi oleh setiap daerah dengan mengacu pada ketentuan yang berlaku. Pemerintah sangat peduli dalam mewujudkan pengelolaan barang milik daerah atau aset yang tertib, dapat dipertanggung jawabkan dan transparan. Peraturan Pemerintah (PP) Nomor 71 Tahun 2010 tentang Standar Akuntansi Pemerintah, PP Nomor 27 Tahun 2014 tentang Pengelolaan Barang Milik Daerah dan Peraturan Menteri Dalam Negeri (Permendagri) Nomor 19 Tahun 2016 tentang Pedoman Pengelolaan Barang Milik Daerah merupakan bukti perhatian pemerintah agar penyusunan laporan tentang barang milik daerah dikelola dengan optimal. Pemerintah daerah melalui Organisasi Perangkat Daerah (OPD) yang ada sebagai pelaksana dan pengguna barang milik daerah diharapkan dapat mengelola secara baik seluruh aset yang dimilikinya. Pengelolaan sebagaimana dimaksud mencakup perencanaan dan penganggaran, pengadaan, penggunaan, pemanfaatan, pengamanan dan pemeliharaan, penilaian, pemindahtanganan, pemusnahan, penghapusan, penatausahaan, pembinaan, pengawasan dan pengendalian.

Terbitnya Undang-Undang (UU) Nomor 23 Tahun 2014 tentang Pemerintahan Daerah, merupakan desentralisasi pembangunan di daerah dan diharapkan dapat mendorong pemerataan pembangunan di daerah. Di era otonomi daerah, pemerintah daerah dalam melakukan implementasi kebijakan pengelolaan barang milik daerah merupakan komponen penting dalam penyelenggaraan kegiatan pengelolaan keuangan daerah. Barang milik daerah atau aset yang dimiliki dari perspektif akuntansi merupakan kekayaan yang mnecakup kekayaan lancar, aset tetap dan harta tak berwujud. Setiap aset yang dikelola dengan baik akan mendatangkan manfaat yang besar dalam menunjang jalannya pemerintahan yang baik pula.

Pengertian aset secara umum menurut Siregar (2004) adalah barang atau sesuatu barang yang mempunyai nilai ekonomi, nilai komersial atau nilai tukar yang dimiliki oleh badan usaha, instansi atau individu.
Berdasarkan pengertian diatas peneliti mengambil kesimpulan bahwa aktiva atau aset adalah bentuk dari investasi, yang terdiri dari harta kekayaan, dan diharapkan mampu memberikan kontribusi baik secara langsung maupun tidak langsung di masa yang akan datang.

Dalam implementasinya, pengelolaan barang milik daerah di Kabupaten Merangin masih ditemukan penyimpangan atau inkonsistensi. Hal ini ditandai dengan kondisi laporan Dinas Pekerjaan Umum dan Penataan Ruang (DPUPR) Kabupaten Merangin, merupakan satuan pelaksana teknis dalam pengelolaan barang milik daerah, dituntut mampu dalam penyajian laporan barang milik daerah dengan baik dan benar.

Menyikapi fakta yang ditemukan di lapangan yaitu adanya inkonsistensi yang terjadi dalam pengelolaan barang milik daerah pada Dinas Pekerjaan Umum dan Penataan Ruang Kabupaten Merangin bahwa aset tetap jalan, irigasi dan jaringan sebanyak 361 unit sebesar Rp 57,76 miliar pada Dinas Pekerjaan Umum dan Penataan Ruang belum ditetapkan statusnya.

\section{METOde PENELITIAN}

Penelitian yang dilakukan oleh penulis adalah dengan menggunakan metode penelitian kualitatif, dengan menggunakan data primer yang bersumber dari hasil wawancara dengan informan yang dipilih dengan methode purposive sampling, sedangkan data sekunder diperoleh dari dokumen-dokumen resmi yang digunakan seperti: hasil wawancara, catatan lapangan, foto, dokumentasi pribadi, catatan, atau memo dan dokumentasi lainnya.Teknik pengumpulan data yang digunakan dalam penelitian ini adalah teknik observasi, teknik wawancara dan teknik dokumentasi.

Penelitian ini menggunakan pendekatan kualitatif. Sebagaimana pendapat Bogdan dan Taylor dalam Basrowi dan Suwandi (2008:1) menyatakan bahwa penelitian kualitatif adalah "salah satu prosedur penelitian yang menghasilkan data deskriptif berupa ucapan atau tulisan dan perilaku orang-orang yang diamati”. Penelitian kualitatif adalah penelitian yang pemecahan masalahnya dilakukan dengan menggunakan data empiris. 


\section{HASIL DAN PEMBAHASAN}

\section{Implementasi Kebijakan Pengelolaan Barang Milik Daerah}

\section{Karakteristik dari Masalah}

Karakteristik masalah adalah bagaimana permasalahan yang terjadi, apakah termasuk permasalahan sosial yang secara teknis mudah diselesaikan atau masuk kategori masalah sosial yang secara teknis sulit untuk dipecahkan. Sebagai contoh masalah sosial yang termasuk kategori mudah diselesaikan adalah seperti kekurangan persediaan beras disuatu daerah, kekurangan guru dalam suatu sekolah, dan lainlain. Untuk contoh masalah sosial yang termasuk kategori sosial yang cukup sulit dipecahkan adalah seperti pengangguran, kemiskinan, dan masalah-masalah lain yang sejenis.

Adapun presentase kelompok sasaran terhadap total populasi dalam artian bahwa suatu program atau kebijakan akan lebih mudah diimplementasikan ketika sasarannya hanyalah sekelompok orang tertentu atau hanya sebagian kecil dari semua populasi yang ada ketimbang kelompok sasarannya menyangkut seluruh populasi itu sendiri.

Aspek di atas digunakan sebagai dasar, petunjuk, maupun peraturan guna menjamin suatu proses pengelolaan barang milik daerah yang telah disepakati. Demikian pula dengan kebijakan pengelolaan barang milik daerah sebagaimana termuat dalam Peraturan Daerah Kabupaten Merangin Nomor o5 Tahun 2017 juga memiliki ukuran atau standar yang jelas dan terukur. Dengan adanya ukuran atau standar maka tujuan kebijakan pengelolaan barang milik daerah dapat terwujud. Namun apabila ukuran atau standarnya kurang jelas apalagi tidak jelas maka akan sulit untuk mencapai tujuan kebijakan tersebut bahkan tidak jarang akan menimbulkan kesalahpahaman (misunderstanding) diantara implementor kebijakan.

Dalam implementasi kebijakan pengelolaan barang milik daerah di Kabupaten Merangin, Dinas Pekerjaan Umum dan Penataan Ruang (Dinas PUPR) bertindak selaku pengguna barang dengan melakukan pengelolaan barang milik daerah yang dikuasai dan terdaftar dalam daftar barang pengguna Dinas PUPR Kabupaten Merangin. Sebagaimana hasil wawancara dengan
Informan Bapak Sularmin (22/o7/2020) selaku Kasubbid BPKAD berkaitan dengan pelaksanaan dan tujuan kebijakan pengelolaan barang milik daerah yaitu:

"bahwa prinsip dasar pengelolaan kekayaan (aset) daerah meliputi tiga hal yang utama, yaitu adanya perencanaan yang tepat, pelaksanaan/ pemanfaatan secara efisien dan efektif, dan pengawasan (monitoring).

Guna memastikan bahwa Perda Nomor o5 Tahun 2017 telah diimplementasikan dengan baik di lingkungan Dinas Pekerjaan Umum dan Penataan Ruang Kabupaten Merangin berkaitan dengan tindak lanjut temuan BPK dalam pengelolaan barang milik daerah, maka penulis mewawancarai Bapak Irwan Suhadi (23/07/2020) selaku Kasubbag Evaluasi \& Pelaporan Inspektorat menjelaskan bahwa:

"untuk Dinas PUPR masih ditemukan temuan yang nilai temuannya cukup besar, memang temuannya bersifat administratif akan tetapi hal ini terjadi berulang-ulang sehingga patut diduga ada inkonsistensi selama ini dalam hal pengelolan barang milik daerah pada dinas PUPR, sehinggatemuannyamenjadibertumpuk dan relative berat untuk menindaklanjutinya. Misalnya banyak aset yang digunakan oleh pihak lain namun masih tercatatat dalam DBMD Dinas PUPR, rekomendasi BPK adalah agar Kepala Dinas PUPR selaku Pengguna Barang mengusulkan penetapan status kepada Bupati Merangin. Kemudian juga temuan dikhawatirkan hilangnya aset karena belum dilakukan pengelompokan aset atau belum dikapitalisasi, hal ini juga sudah dari beberapa tahun yang lalu menjadi temuan, tetapi belum ada progress penyelesaiannya”.

Dari pernyataan di atas dapat diketahui bahwa secara administrasi pelaporan aset Dinas Pekerjaan Umum dan Penataan Ruang Kabupaten Merangin khususnya untuk pelaporan rekonsiliasi aset semesteran masih mengalami kekurangan, dan perlu penyempurnaan terhadap barang milik daerah yang termasuk dalam balanja modal dan memang pembangunannya diperuntukkan untuk kelompok masyarakat, yayasan, desa, instansi vertikal dan lainnya, agar segera ditindak lanjuti dengan mengusulkan kepada Bupati agar dihibahkan kepada pihak pengguna sesuai dengan peruntukannya. 


\section{Analisis Implementasi Pengelolaan Barang Milik Daerah Pada Dinas Pekerjaan Umum dan Penataan Ruang Kabupaten Merangin \\ Dori Nofriadi}

Selain faktor tingkat kesulitan sebuah masalah atau urusan, juga faktor ketersediaan teknologi dan sifat dari populasi itu sendiri. Bahwa ketersedian anggaran untuk pengadaan alat teknologi dan informasi menjadi kebutuhan dalam pengelolaan barang milik daerah mengingat kendala-kendala yang ditemukan, sehingga penyediaan sarana pendukung keberhasilan kinerja harus didukung. Hal ini sudah saatnya bagi pengelola barang di OPD mendapatkan fasilitas yang memadai dalam rangka mengelola barang yang nilainya tidak sedikit seperti adanya sebuah aplikasi dalam penggunaan barang inventaris khususnya untuk kendaraan dinas atau peralatan mesin, dimana di dalamnya berisi data pengguna berdasarkan NIK, data barang yang digunakan dan ketentuanketentuan serta pernyataan atau kuasa dari penggunaannya yang disepakati di atas materai cukup.

\section{Karakteristik Kebijakan/Undang-Undang}

Keberhasilan implementasi kebijakan dapat dinilai dari sejauh mana sebuah kebijakan yang diambil oleh pembuat kebijakan haruslah mengandung konten yang jelas dan konsisten. Kebijakan dengan isi yang jelas akan memudahkan sebuah kebijakan dan akan menghindarkan distorsi atau penyimpangan dalam pengimplementasiannya. Hal ini dikarenakan jika suatu kebijakan sudah memiliki isi yang jelas maka kemungkinan penafsiran yang salah oleh implementor akan dapat dihindari dan sebaliknya jika isi suatu kebijakan masih belum jelas atau mengambang, potensi untuk distorsi ataupun kesalahpahaman akan besar.

Karakteristik kebijakan dalam hal ini aturan yang mengatur tentang pengelolaan barang milik daerah dapat berpengaruh terhadap kesuksesan implementasi sebuah kebijakan. Untuk pelaksanaan kebijakan diperlukan standar operasional prosedur (SOP) dalam mengerjakan suatu, diharapkan SOP dimaksud dapat dilaksanakan sehingga langkah-langkah pengelolaan barang milik daerah dapat terperinci dengan sistematis. Menurut Ambuon Ardiansyah, SH bahwa untuk melengkapi Perda Kabupaten Merangin Nomor 5 tahun 2017 sedang dirancang Peraturan Bupati tentang penghapusan barang milik daerah, namun secara umum sudah diatur dalam Perda
Nomor 5 tahun 2017 baik tentang penggunaan/ pemanfaatan, pengamanan dan pemeliharaan, pemindahtanganan dan penghapusan.

Kemudian dalam mendukung pengimplementasian suatu kebijakan adalah masalah keuangan/modal. Setiap program tentu memerlukan staff untuk melakukan pekerjaanpekerjaan administrasi dan teknis, memonitor program, dan mengelola sumberdaya lainnya yang kesemua itu memerlukan modal. Suatu program akan dengan sukses diimplementasikan jika terjadi koordinasi yang baik yang dilakukan antar berbagai instansi terkait baik secara vertical maupun horizontal.

Selanjutnya ketersediaan anggaran untuk pengelolaan barang milik daerah di Dinas Pekerjaan Umum dan Penataan Ruang Kabupaten Merangin belum memadai, sehingga pengelola barang terkendala dalam melakukan kegiatan ke lapangan secara optimal seperti melakukan koordinasi dan cek fisik terhadap aset yang tercatat dalam daftar barang pengguna, melakukan validasi atas penelusuran yang dilakukan oleh Tim Inventarisasi Aset Dinas Pekerjaan Umum dan Penataan Ruang Kabupaten Merangin hal ini melibatkan Tim Aset BPKAD Kabupaten Merangin dan Tim Inspektorat Kabupaten Merangin.

Untuk menghasilkan pengelolaan barang milik daerah yang optimal sangat diperlukan dukungan anggaran, hal ini merupakan langkah positif dimana selama ini terkendala dalam penganggaran di OPD, saat ini berdasarkan Permendagri Nomor 90 Tahun 2019 bahwa anggaran untuk pengelolaan barang milik daerah di OPD dapat diusulkan semoga kebutuhan penunjang kinerja untuk tahun anggaran 2021 dapat direalisasikan. Hal ini sesuai dengan ketentuan yang berlaku dalam Permendagri Nomor 19 Tahun 2016 bahwa Kepala OPD bertanggung jawab dalam mengelola barang yang dikuasainya, untuk itu masing-masing OPD dapat menyesuaikan kebutuhan anggarannya untuk pengelolaan barang milik daerah di OPD tetap berjalan dengan baik.

Dari hasil wawancara kepada informan, masih terdapat beberapa hal yang mesti disempurnakan dalam rangka menertibkan pengelolaan aset di Dinas PUPR, kedepan seperti dukungan untuk peningkatan sumberdaya yang mantap, dukungan moril dan materil dari para Kabid dan seluruh karyawan serta rekrutmen 
pengelola aset yang kompeten di bidangnya sehingga kebijakan yang ditetapkan dapat diimplementasikan dengan baik. Kemudian untuk memudahkan dalam hal inventarisasi barang milik daerah juga dipandang perlu untuk menyiapkan alat teknologi aplikasi terkait penggunaan dan pengamanan barang milik daerah seperti data pengguna barang inventaris terdaftar dalam system dan tidak dapat dirubah datanya kecuali melengkapi syarat yang teah ditentukan seraya diperkuat dengan penekanan sanksi bagi yang tidak mematuhinya.

Hasil penelitian menunjukkan bahwa kebijakan pengelolaan barang milik daerah telah dilakukan tetapi masih perlu ditingkatan lagi terkait komunikasi yang baik antara pihak pengelola aset Dinas Pekerjaan Umum dan Penataan Ruang Kabupaten Merangin, pembantu pengelola aset di unit kerja dan Bidang Aset BPKAD Kabupaten Merangin. Hal ini ditandai dengan rendahnya progress penyelesaian tindak lanjut temuan BPK terkait penetapan satus penggunaan aset, kapitalisasi aset dan permasalahan lainnya pada Dinas Pekerjaan Umum dan Penataan Ruang Kabupaten Merangin.

Pengelola barang yang ditunjuk hendaknya memiliki kriteria dasar seperti dalam hal pangkat dan golongan, sebab apabila pengurus barang ditunjuk kepada yang telah menduduki golongan III, maka perluanya untuk berpindah karena promosi tidak dapat dielakkan pada prinsipnya dalam kepegawaian promosi adalah jenjang karir yang harus dijalani. Jadi alangkah baiknya yang menduduki jabatan pengurus barang adalah maksimal dari golongan II diharapkan akan dapat lama bertahan menjadi pengelola barang.

Dari uraian di atas dapat disimpulkan bahwa kebijakan tentang rekrutmen pejabat pelaksana dalam hal ini pengelola barang dapat dipilih dengan syarat yang bersangkutan memiliki kemauan yang tinggi dalam melakukan pengelolaan aset, selanjutnya diiringi dengan meningkatkan kemampuannya melalui pembekalan dengan ikut bimbingan teknis baik di OPD maupun bimbingan teknis yang diselenggarakan oleh pihak resmi yang melaksanakan bimbingan teknis. Dengan demikian diharapkan kapasitasnya bertambah sehingga dapat menunjang keberhasilan implementasi kebijakan di OPD.

\section{Variabel Lingkungan}

Keberhasilan implementasi kebijakan pengelolaan barang milik daerah di Dinas Pekerjaan Umum dan Penataan Ruang Kabupaten Merangin dapat dilihat dari kondisi sosial ekonomi masyarakat menyangkut akan hal keadaan suatu masyarakat secara umum, mulai dari pendidikan, keadaan ekonomi, dan kondisi sosialnya. Hal ini disebabkan karena hasil implementasi kebijakan pengelolaan barang milik daerah akan dipengaruhi oleh keadaan masyarakat yang sudah terbuka dan modern dengan masyarakat yang tertutup dan tradisional. Masyarakat yang sudah terbuka akan lebih mudah menerima program-program pembaharuan daripada masyarakat yang masih tertutup dan tradisional. Sementara itu, teknologi sendiri adalah sebagai pembantu untuk mempermudah pengimplementasian sebuah program. Teknologi yang semakin modern tentu akan semakin mempermudah.

Variabel lingkungan mencakup dukungan publik, sikap dan sumber daya kelompok sasaran utama, dukungan kewenangan dan komitmen kemampuan pejabat. Semua hal tersebut yang terjadi akan mempengaruhi implementasi kebijakan pengelolaan barang milik daerah. Menurut Erika Sari, A.Md terkait upaya yang telah dilakukan oleh Pengurus Barang selama ini bahwa untuk aset yang dikuasai oleh pihak lain yang tidak berhak, diperlukan regulasi yang dapat dijadikan pedoman dan bantuan dari pihak terkait dalam melakukan penertibannya.

Jadi dalam hal ini Pengurus Barang Dinas Pekerjaan Umum dan Penataan Ruang Kabupaten Merangin memiliki keterbatasan dalam bertindak atau melakukan upaya penyelesaian permasalahan yang ada karena pengelolaan aset masih dipandang sebelah mata bagi sebagian pihak, padahal mulai dari perencanaan pengadaan barang milik daerah, pemanfaatan, pemeliharaan dan penghapusan merupakan bagian dari ruang lingkup pengelolaan barang milik daerah yang mesti dilakukan oleh Pengelola Barang.

Upaya yang telah dilakukan oleh pengurus barang pengguna sesuai dengan tugas dan fungsinya sebagaimana diatur dalam Perda Kabupaten Merangin Nomor 5 Tahun 2017 yaitu membantu mengamankan barang milik daerah yang berada pada pengguna barang, 
seperti kendaraan yang dikuasai oleh pihak luar tersebut masih tercatat dalam daftar barang pengguna Dinas Pekerjaan Umum dan Penataan Ruang Kabupaten Merangin, akan tetapi belum dikembalikan oleh penggunanya sehingga diperlukan tindakan yang melibatkan Tim Penertiban Aset Kabupaten Merangin.

Faktor-faktor yang mempengaruhi implementasi kebijakan pengelolaan barang milik daerah

Implementasi pengelolaan barang milik daerah sesuai dengan Peraturan Daerah Kabupaten Merangin Nomor o5 Tahun 2017 sudah dilaksanakan oleh Dinas Pekerjaan Umum dan Penataan Ruang Kabupaten Merangin, namun dalam pengimplementasiannya masih ditemukan beberapa hambatan. Menurut Kepala Bidang Tata Ruang Sarbaini, SE., MT mengatakan bahwa penggunaan teknologi sebaiknya dapat dilaksanakan untuk mempermudah kerja karena zaman sekarang sudah serba komputer pekerjaan yang sulit dapat menjadi mudah. Kemudian menurut Kepala Bidang Bina Konstruksi, faktor yang sangat berpengaruh yaitu rekrutmen pejabat pelaksana dalam hal ini pelaksana pengelola barang milik daerah dan pemberian insentif. Hal ini merupakan bagian dari kebijakan pimpinan yang menunjuk personil selaku pengelola barang yang mampu bekerja secara tim.

Pengurus Barang menyatakan bahwa dukungan anggaran seperti biaya lembur untuk makan minum, biaya perjalanan dinas untuk penelusuran barang milik daerah, biaya pembelian materai untuk penandatanganan berita acara atau dokumen penting lainnya dan juga dukungan fasilitas diantaranya GPS, laptop dan kamera merupakan faktor penting dalam mensukseskan kebijakan implementasi barang milik daerah.

\section{KESIMPULAN DAN SARAN}

Berdasarkan pembahasan di atas, dapat disimpulkan bahwa implementasi pengelolaan barang milik daerah pada Dinas Pekerjaan Umum dan Penataan Ruang Kabupaten Merangin belum optimal dilaksanakan sesuai kebijakan. Hal ini ditandai dengan masih adanya inkonsistensi dalam penerapan Peraturan Daerah Kabupaten Nomor 5 Tahun 2017 terutama dalam hal penggunaan/pemanfaatan, pengamanan dan pemeliharaan, serta pemindahtanganan dan penghapusan barang milik daerah.

Adapun faktor-faktor yang mempengaruhi implementasi kebijakan pengelolaan barang milik daerah pada Dinas Pekerjaan Umum dan Penataan Ruang Kabupaten Merangin dapat dipengaruhi oleh beberapa variabel yaitu karakteristik masalah, karakteristik kebijakan/ undang-undang dan variable lingkungan. Rincian variable tersebut diantaranya: (1) masalah lokasi barang milik daerah berada di 24 Kecamatan dalam Kabupaten Merangin, dan masih rendahnya kesadaran serta rasa tanggung jawab maupun sikap kooperatif personil dalam pengelolaan barang milik daerah, (2) masalah kebijakan rekrutmen pengelola barang milik daerah belum tepat dan terukur, dan masih kurangnya pelaksanaan sosialisasi untuk peningkatan kapasitas pengelola barang milik daerah,(3)masalahdukunganlingkungandimana masih minimnya penggunaan alat teknologi yang dapat memudahkan pekerjaan, dan anggaran yang kurang memadai. Berdasarkan kesimpulan di atas, maka disarankan kepada Pemerintah Kabupaten Merangin dapat berkomitmen dalam bidang penganggaran untuk menjalankan amanah Peraturan Daerah Nomor 5 Tahun 2017 tentang Pengelolaan Barang Milik Daerah yang dapat digunakan untuk biaya pengelolaan barang milik di OPD. Selanjutnya perlu dilakukan upaya sosialisasi dan pengadaan alat teknologi serta peningkatan kapasitas pengelola barang milik daerah pada Dinas Pekerjaan Umum dan Penataan Ruang Kabupaten Merangin.

\section{DAFTAR PUSTAKa}

\section{Buku}

Agustino, L. (2012). Dasar-dasar Kebijakan Publik. Jakarta: CV. Alfabeta.

Alisjahbana. (2006). Marginalisasi Sektor Informal Perkotaa. ITS Press Surabaya.

Aneta, A. (2010). Implementasi Kebijakan Program Penanggulangan Kemiskinan Perkotaan ( P2KP) di Kota Gorontalo, Jurnal Administrasi Publik.

Danim. (2004). Sumber Daya Manusia. Jakarta: Grafindo Persada

Donal, V, M, and Carl E. V. H. (2008). The Policy Impelemntation Prosess. Beverly Hill: Sage Publication.

Edi, S. (2008). Kebijakan Sosial Sebagai Kebijakan Publik, Bandung: Alfabeta.

Hardjito, Dydiet. (2001). Teori Organisasi Dan Teknik Pengorganisasian. Jakarta: Raja Grafindo Persada. 
JIADI: Jurnal Ilmu Administrasi dan Pemerintahan Indonesia Volume 02 No o1 June 2021

Pages 50-56

Islamy. M. Irfan. (2002). Prinsip-prinsip perumusan Kebijakan Negara. Bumi Aksara. Jakarta

Kunto, dan Hamidjoyo. (2005). Analisis Faktor-Faktor yang mempengaruhi keberhasilan implementasi kebijakan penataan, pembinaan, dan penertiban pedagang kaki lima di Surakarta. Semarang: Undip.

Mahmudi. (2005). Manajemen Kinerja Sektor Publik. Yogyakarta: YKPN.

Mardiasmo. (2002). Akuntansi Sektor Publik. Jakarta: Andi.

Riant, N, D. (2008). Kebijakan publik untuk Negara-Negara Berkembang. Jakarta: PT Alex Media Komputindo.

Siregar, D, D. (2004). Manajemen Aset. Jakarta: Satyatama Tara.

Suwitri, S, Purnaweni, H, dan Kismartini. (2015). Analisis Kebijakan Publik. Tangerang Selatan: Penerbit Universitas Terbuka.

\section{Peraturan Perundang-Undangan}

Undang-Undang Nomor 23 Tahun 2014 Tentang Pemerintahan Daerah
Peraturan Menteri Dalam Negeri Nomor 19 Tahun 2016 tentang Pengelolaan Barang Milik Daerah

Peraturan Daerah Kabupaten Merangin Nomor o5 Tahun 2017 tentang Pengelolaan Barang Milik Daerah

\section{Dokumen dari Internet}

Manajemen Aset Menurut Para Ahli. Diunduh 26 Januari 2016, dari situs Word WideWeb:http:// ajengfitrianimutia.blogspot.com/2016/01/definisimanajemen-aset-menurut-para.html

https://wwwgurupendidikan.co.id/pengertian-aset Pengertian Manajemen Aset, Menurut Ahli, Tujuan dan Siklusnya. dari situs Word Wide Web https://www. seputarpengetahuan.co.id/2019/11/manajemenaset.html\#Menurut_Gima_Sugiama_2013

Memahami Pentingnya Pengelolaan Aset di PTNBH. Diunduh 14 September 2016, dari situs Word Wide Web: https://www.ui.ac.id/memahami-pentingnyasistem-pengelolaan-aset-di-ptnbh/

http://repository.uinsuska.ac.id/4174/3/11.\%20BAB\%20 II.pdf 